\title{
17 Arsenic speciation and mobility in mine wastes from a copper-arsenic mine in Devon, UK: an SEM, XAS, sequential chemical extraction study
}

\author{
Barbara Palumbo-Roe, Ben Klinck, Mark Cave \\ British Geological Survey, Keyworth, Nottingham NG12 5GG, UK
}

\begin{abstract}
The nature of As speciation is a determining factor for As mobility in mine wastes. In this study, scanning electron microscopy (SEM), X-ray absorption spectroscopy and sequential chemical extraction methods were used for the environmental, mineralogical and genetic characterisation of mine spoil and calciner wastes from Devon Great Consols Mine, an abandoned copper-arsenic mine in Devon, UK. The geochemical control of As-bearing phases on dissolved As during leaching was investigated.

Arsenic is mainly present as $\mathrm{As}(\mathrm{V})$ co-precipitated or adsorbed with, or on, iron oxyhydroxides. The water extracts from the mine spoil and calciner wastes indicated a generally low dissolution of As, especially in sandy tailings ( $\mathrm{As}_{\text {water soluble }} 0.0004 \%$ of total As content). Thermodynamic calculations did not identify a major As phase controlling the composition of the water leachates, which suggests a process of desorption of iron oxyhydroxide-bound As as the source of As in the solution. A relative higher As mobility ( $\mathrm{As}_{\text {water soluble }} 3.7 \%$ of total As content) was found in the waste material with an alkaline $\mathrm{pH}$ in the vicinity of the ore crusher. Available thermodynamic data supported by SEM evidence and chemical extraction data suggest that calcium-arsenate phases such as weillite $\left(\mathrm{CaHAsO}_{4}\right)$ and calcium-copper arsenates together with scorodite $\left(\mathrm{FeAsO} \mathrm{A}_{4} \cdot 2 \mathrm{H}_{2} \mathrm{O}\right)$ and iron oxyhydroxides may all contribute to the higher As content in the alkaline waste leachates. The results indicate the importance of considering the nature of As in mine waste management.
\end{abstract}

\subsection{Introduction}

England has a legacy of metalliferous mining possibly extending back to Roman times. A knowledge of the evolution of mine wastes and dispersion patterns is required to reduce concern in respect of the health hazard 
associated with mining activities. Intensive exploitation of metalliferous ore deposits, combined with the natural geochemical dispersion from the coppertin-arsenic mineralisation, has resulted in the creation of a significant area of As-contaminated wastes and soils in southwestern England (Mitchell and Barr, 1995). The levels of As contamination in soils and rivers are well documented (Aston et al., 1975; Colbourn et al., 1975; Abrahams and Thornton, 1987). However, less attention has been devoted to studying the solid partitioning and speciation of As in the region. In the present study, we aim to describe the distribution and mobility of As in the wastes formed from various stages of the ore dressing process of Devon Great Consols Mine, an abandoned copper-arsenic mine in West Devon, UK. For this purpose, the complementary application of direct and indirect methods of analysis has been used. The information provided can certainly contribute to assessing the environmental risk related to these mine wastes. This study is part of a larger project carried out by the British Geological Survey to study dispersion of mine pollution in the UK (Klinck et al., in press).

\subsection{Materials and methods}

\subsubsection{Study area}

The Devon Great Consols Mine lies on the east bank of the river Tamar in the Tavistock District in Devon, UK (Fig. 17-1). The mine, deriving from the consolidation of five adjacent mines, worked on lodes mainly consisting of chalcopyrite, pyrite and some arsenopyrite and cassitierite with quartz, fluorite and brecciated country rock cemented by chlorite or siderite.

In the nineteenth century Devon Great Consols was the richest and largest mine in the Tamar valley and an output of over $70000 \mathrm{t}$ of As between 1848 and 1909 has been recorded (Dines, 1956). Mining activity at Devon Great Consols ended in 1930.

\subsubsection{Methods of As production}

A comprehensive review of the method of As production at Devon Great Consols can be found in Pye and Dixon (1989). The following is a brief summary that outlines the main stages resulting in the output of refined As. The As works, whose features are still partially visible, from 1921 to 1925 was involved in the processing, calcining, refining and milling of the ore collected on site. 


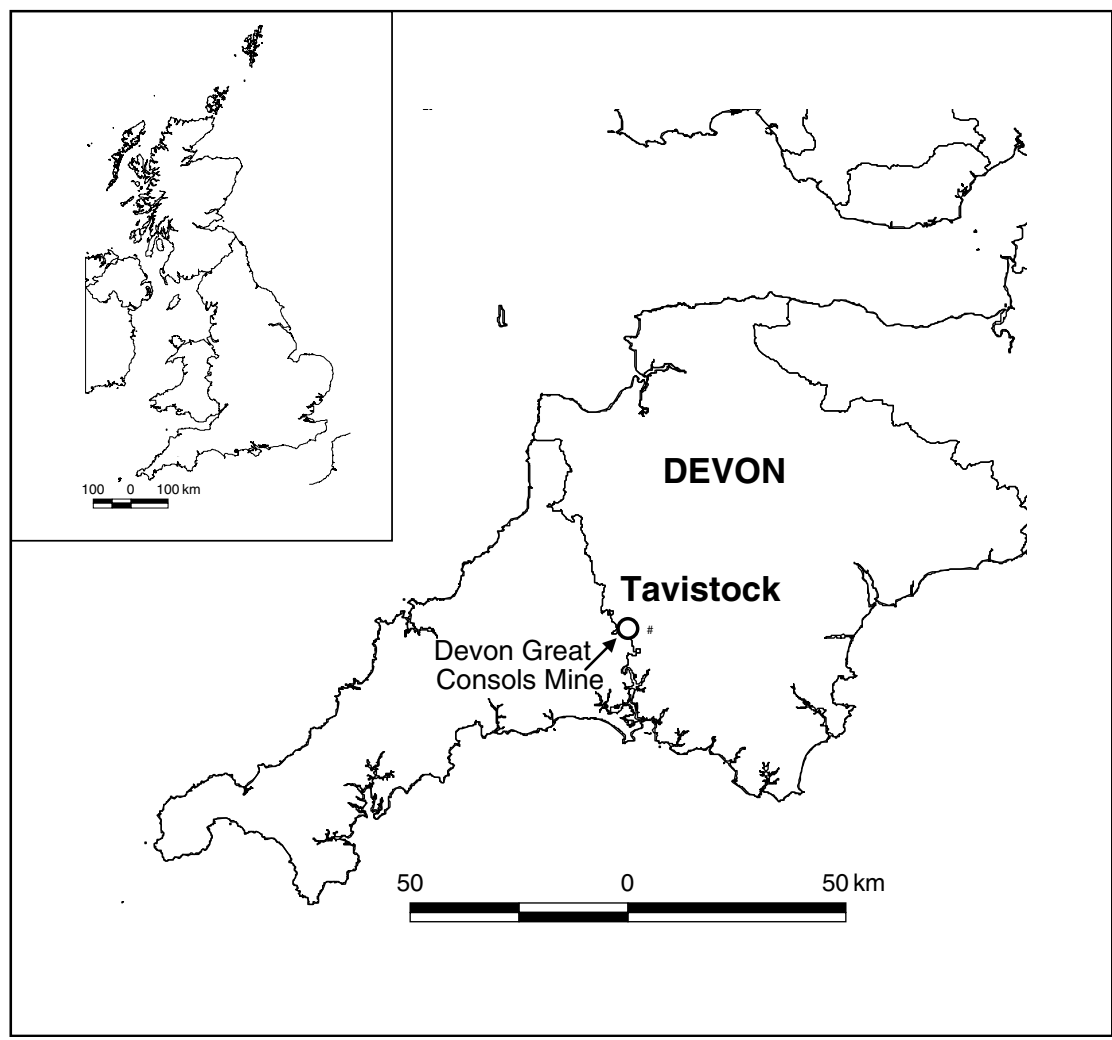

Fig. 17-1: Location of Devon Great Consols Mine

The ore was brought to the As works from the various working mines and waste dumps. It was reduced to small pieces by a crusher and then washed and sorted by large mechanical sieves powered by waterwheels. The processed ore was then roasted in a pre-heated furnace, usually between $538^{\circ} \mathrm{C}$ and $593^{\circ} \mathrm{C}$, when the most efficient sublimation of As occurs. After calcination, the fumes passed along flues in which the grey 'crude' As soot was precipitated when the temperatures fell below $171^{\circ} \mathrm{C}$. After collection from the condensing chambers, the crude As was recalcined to achieve the degree of purity $(99.5 \%)$ necessary for sale. After passing through the condensers, most of the unprecipitated arsenic and sulphur fumes were removed in the flue prior to emission from the stack, so as to reduce pollution of the surrounding land. In the flue, the fumes passed through a water shower over soaked wooden beams. Additional limestone within the flue helped reduce further 
the sulphur dioxide emission. A high stack $(36 \mathrm{~m})$ at the end of the flue facilitated the dispersal of the remaining fumes, as well as providing a draught for the calcining furnaces.

\subsubsection{Sample collection and preparation}

The Devon Great Consols Mine includes the As processing plant and associated waste dumps and ponds for the settling out of residues and waste from the crushed ore. At the processing plant, samples were collected from the crusher area (MPS97) where the ore was reduced to pea-sized pieces and from the black furnace slag heaps (MPS73-MPS90). Efflorescent masses of As-bearing salts on the brickwork of the calciner building were also sampled. Additional material was collected from the sandy calciner residues from various waste dumps scattered throughout the site.

Where soil/waste samples were collected, each sample $(0-15 \mathrm{~cm}$ depth $)$ was made of a composite of material from auger flights taken from five holes distributed within an area of $1 \mathrm{~m} \times 1 \mathrm{~m}$.

\subsubsection{Analytical methods}

\section{Chemical analysis}

All samples were air-dried and sieved to $<250 \mu \mathrm{m}$. Total element content of the $<250 \mu \mathrm{m}$ fraction was obtained by inductively coupled plasma emission spectroscopy (ICP-AES) after digestion of the samples with a mixture of hydrofluoric, perchloric and nitric acids. The $\mathrm{pH}$ was measured in $0.01 \mathrm{M}$ $\mathrm{CaCl}_{2}$ solution and cation exchange capacity (CEC) by titration.

\section{Partitioning by sequential extraction}

Chemical sequential extraction was carried out in order to characterise element partitioning in the solid phase. Two grams of the sample were supported on a filtration membrane in a centrifuge tube. Extraction was then carried out using first, for steps 1 and 2, de-ionised water (DIW) and then separate aliquots of $\mathrm{HNO}_{3}$ of increasing concentration, which were passed through the sample under centrifugal force. Each extraction step was carried out twice [0.01 $\mathrm{M}$ (steps 3 and 4), $0.05 \mathrm{M}$ (steps 5 and 6), $0.1 \mathrm{M}$ (steps 7 and 8), $0.5 \mathrm{M}$ (steps 9 and 10), $1 \mathrm{M}$ (steps 11 and 12), $5 \mathrm{M}$ (steps 13 and 14) $\mathrm{HNO}_{3}$ ] and $10 \mathrm{ml}$ of the leaching solution used. For the $0.1,0.5,1$ and $5 \mathrm{M}$ acid extracts, $0.25,0.50,0.75$ and $1 \mathrm{ml}$, respectively, of hydrogen peroxide were also added 
to each extractant before making up to $10 \mathrm{ml}$ volume. The solutions obtained were analysed for major and trace elements by ICP-AES. A data-processing algorithm was used to identify the number of physico-chemical components extracted, their composition and the proportion of each in each extract according to the Chemometric Identification of Substrates and Element Distributions (CISED) method described in Cave et al. (2004). The chemometric data-processing is based on the assumption that the material is made up of a mixture of discrete physico-chemical components characterised by a distinct element composition. Under increasing acid concentration, each physicochemical component will dissolve according to its degree and rate of solubility. This non-specific extraction approach has already been shown to have a number of analytical advantages over traditional specific extraction schemes, e.g. Tessier's scheme and modified versions (Tessier et al., 1979; Li et al., 1995), and the CISED method has demonstrated the ability to clearly identify physico-chemical components in the soil which have been confirmed by mineralogical analysis (Cave et al., 2004).

\section{Mineralogical and scanning electron microscopy analysis}

Selected tailings samples were analysed by X-ray diffraction (XRD) using Co

AU1 K $\alpha$ radiation. XRD analysis was performed from 3 to $65^{\circ} 2 \theta$ at a scanning speed of $0.7^{\circ} 2 \theta / \mathrm{min}$.

Separate samples of tailings and mine spoil, selected to be representative of the mine waste types occurring at the site, were collected in situ in $50 \mathrm{~mm} \times 100 \mathrm{~mm}$ aluminium boxes ('Kubiena soil tins') to minimise sampling disturbance and preserve any delicate authigenic secondary mineral fabrics. These samples were air-dried in the aluminium boxes and then impregnated, under vacuum, with epoxy resin to stabilise the material for thin-section preparation. The samples were then cut and prepared as uncovered, polished thin sections.

The thin sections were briefly examined with an optical petrographic microscope (in transmitted and reflected light) prior to detailed petrographic characterisation using backscattered scanning electron microscopy (BSEM). Backscattered scanning electron microscopy observations were made using an LEO 435VP variable pressure digital SEM instrument. This was equipped with a KE Developments four-element solid-state backscattered electron detector, and an Oxford Instruments ISIS 300 digital energy-dispersive X-ray microanalysis system. The SEM instrument was operated in the low vacuum mode, at a vacuum of $0.3-0.4$ torr, enabling the polished thin sections to be observed without the need for coating the samples with an electrically conductive film. Observations were recorded using a beam accelerating potential of $10-20 \mathrm{kV}$, 
probe currents of 100-700 pA, and a working distance of 18-25 mm. Mineral identifications were based on the evaluation of semi-qualitative microchemical information obtained from EDXA spectra recorded simultaneously during BSEM observation. In addition, SEM observations were made on individual grains loosely dispersed onto a carbon adhesive tab and sputter coated with a conductive layer of gold metal. The efflorescent masses of As-bearing salts on the brickwork at the furnace site were also analysed.

\section{X-ray absorption spectroscopy analysis}

X-ray absorption spectra at the As K-edge were collected on Station 16.5 at the CLRC Daresbury SRS operating at $2 \mathrm{GeV}$ with an average current of $140 \mathrm{~mA}$, using a vertically focussing mirror and a sagitally bent focussing $\operatorname{Si}(2 \quad 20)$ double crystal monochromator detuned to $80 \%$ transmission to minimise harmonic rejection. Data were collected with the station operating in fluorescence mode using an Ortec 30-element solid-state Ge detector. Experiments were performed at ambient temperature. Single scans were sufficient for most samples, but for two dilute samples multiple scans were collected and averaged to improve the signal-to-noise ratio.

Background-subtracted extended X-ray absorption fine structure (EXAFS spectroscopy) spectra were analysed in EXCURV98 using fullcurved wave theory (Gurman et al., 1984; Binsted, 1998). Phase shifts were derived in the program from ab initio calculations using Hedin-Lundqvist potentials and von Barth ground states (Hedin and Lundqvist, 1969). Fourier transforms of the EXAFS spectra were used to obtain an approximate radial distribution function around the central As atom (the absorber atom); the peaks of the Fourier transform can be related to 'shells' of surrounding backscattering atoms characterised by atom type, number of atoms in the shell, the absorber-scatterer distance, and the Debye-Waller factor, $2 \sigma^{2}$ (a measure of both the thermal motion between the absorber and scatterer and of the static disorder or range of absorber-scatterer distances). The data were fitted for each sample by defining a theoretical model and comparing the calculated EXAFS spectrum with the experimental data. Shells of backscatterers were added around the As and by refining an energy correction $E_{\mathrm{f}}$ (the Fermi energy), the absorber-scatterer distance and Debye-Waller factor for each shell, a least-squares residual, the $R$-factor (Binsted et al., 1992), was minimised. For the first shell of scatterers around the As, the number of atoms in the shell was chosen as the integer that gave the best fit but was not further refined. Arbitrary numbers of atoms were chosen for the outer shells. 


\subsubsection{Thermodynamic data}

Simulations were performed using the geochemical model PHREEQC (Parkhurst, 1995) with the WATEQ4F thermodynamic database (Ball and Nordstrom, 1991) (Table 17-1) for the purpose of calculating the degree of saturation of the minerals in equilibrium with the water leachates extracted in the first two steps of the sequential extraction. Solubility data for weillite $\mathrm{CaHAsO}_{4}$, olivenite $\mathrm{Cu}_{2}\left(\mathrm{AsO}_{4}\right)(\mathrm{OH})$ and conichalcite $\mathrm{CaCu}\left(\mathrm{AsO}_{4}\right)(\mathrm{OH})$ were added from the database compiled by Gaskova et al. (2001).

The degree of saturation of a mineral with respect to the solution in contact with the mineral is expressed as saturation index (SI). The SI is calculated from the equation:

$$
\mathrm{SI}=\log \left(\mathrm{IAP} / K_{\mathrm{sS}}\right)
$$

where IAP is the ionic activity product of the specific reaction and $K_{\mathrm{ss}}$ is the equilibrium constant (Table 17-1).

\subsection{Results and discussion}

\subsubsection{Bulk chemistry of the tailings and mine wastes}

All tailings and mine waste samples exhibit elevated As values with a range from 1280 to $205000 \mathrm{mg} / \mathrm{kg}$ (Table 17-2). Samples are also typically enriched in iron (39600-306 $000 \mathrm{mg} / \mathrm{kg}$ ) and in many samples high sulphur content is displayed (up to $22400 \mathrm{mg} / \mathrm{kg}$ ). Copper contents range between 27 and $20900 \mathrm{mg} / \mathrm{kg}$. Sample MPS73, the black furnace slag material mixed with waste rocks and bricks, shows the highest concentrations of arsenic, copper and zinc. Low acidic $\mathrm{pH}$ is also characteristic of the tailings and mine waste. The only sample showing a neutral $\mathrm{pH}$ of 7 was taken from the area of the relict ore crusher (MPS97). This higher $\mathrm{pH}$ together with relatively enriched calcium content might be due to the practice of lime addition during the ore processing described by Pye and Dixon (1989).

\subsubsection{Mineralogic/petrographic characterisation}

\section{Sandy tailings}

The mineralogy of the sandy tailings, based on XRD analysis, is dominated by the gangue minerals (quartz, mica and chlorite). Minor amounts of pyrite, arsenopyrite, cassitierite and fluorite are also present. The relatively high 


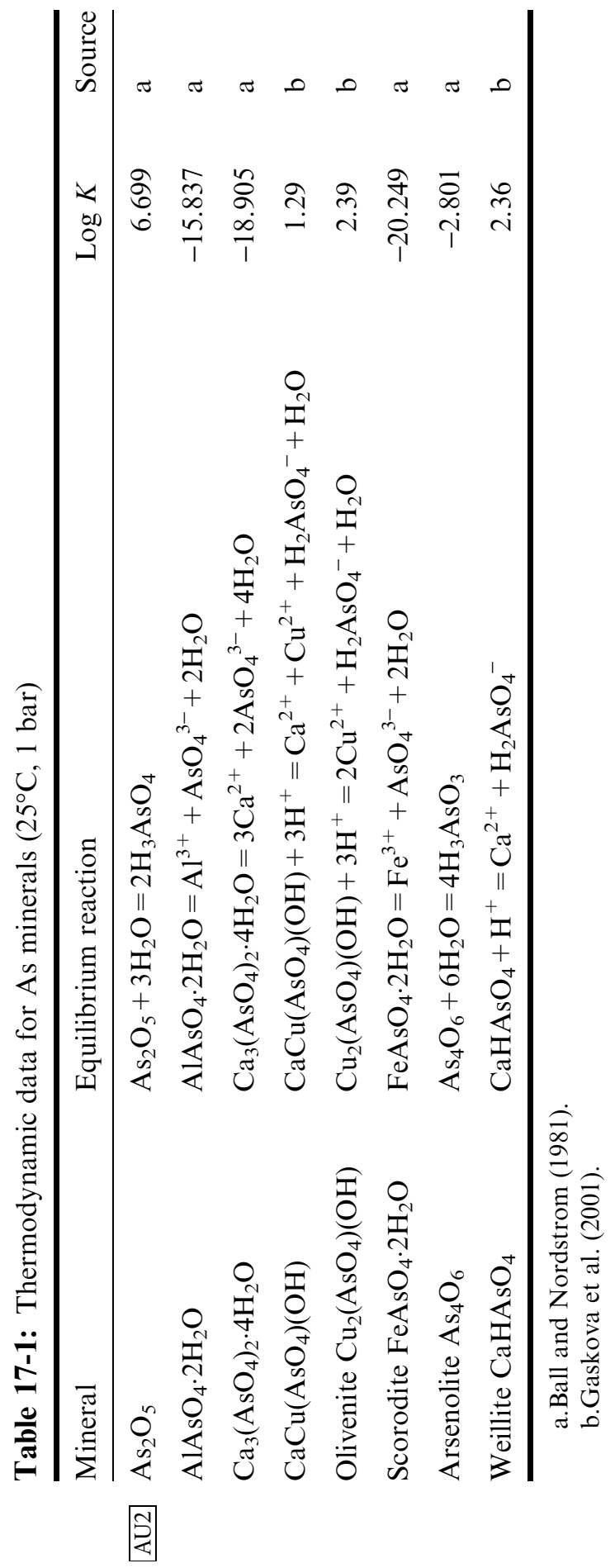




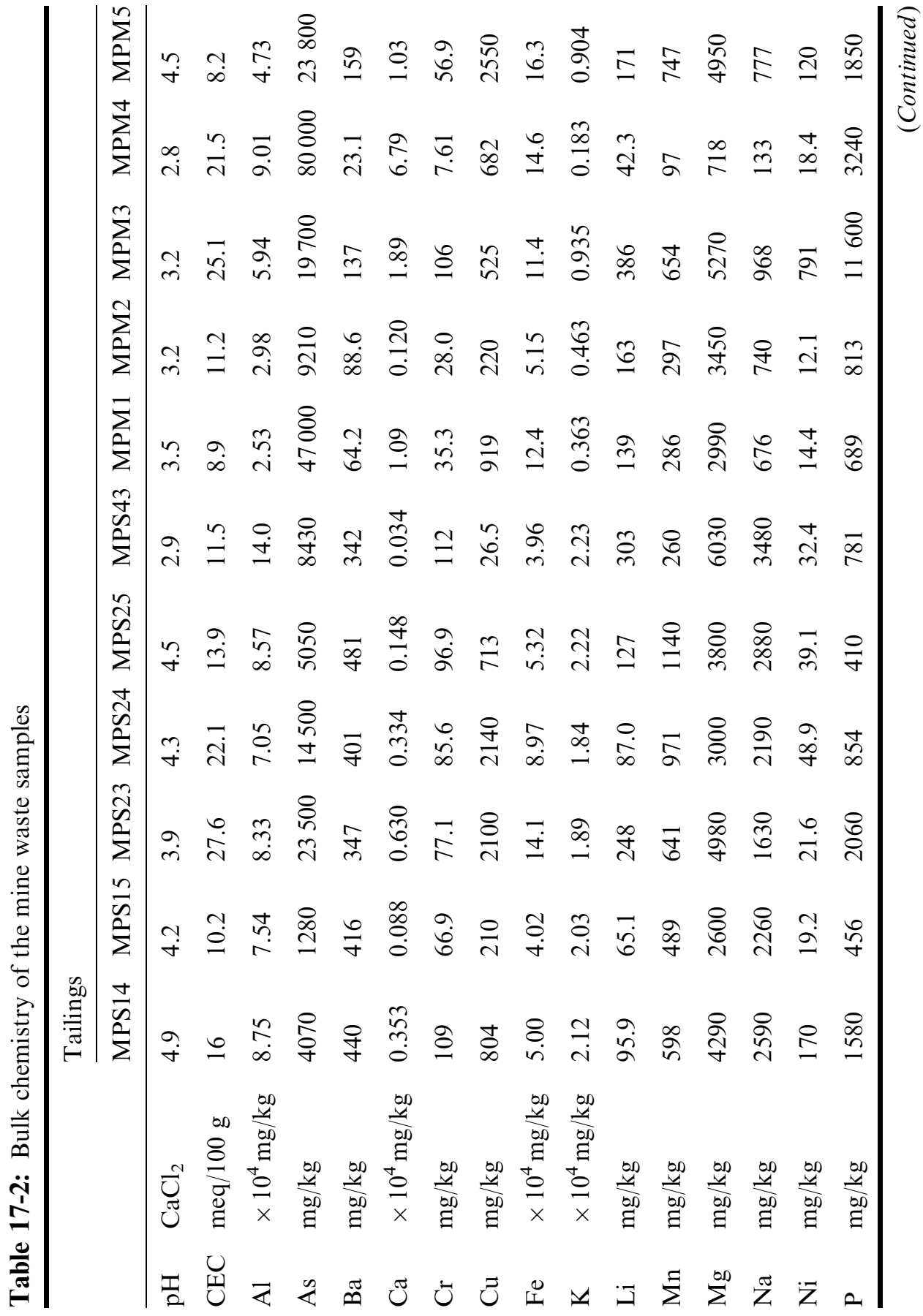




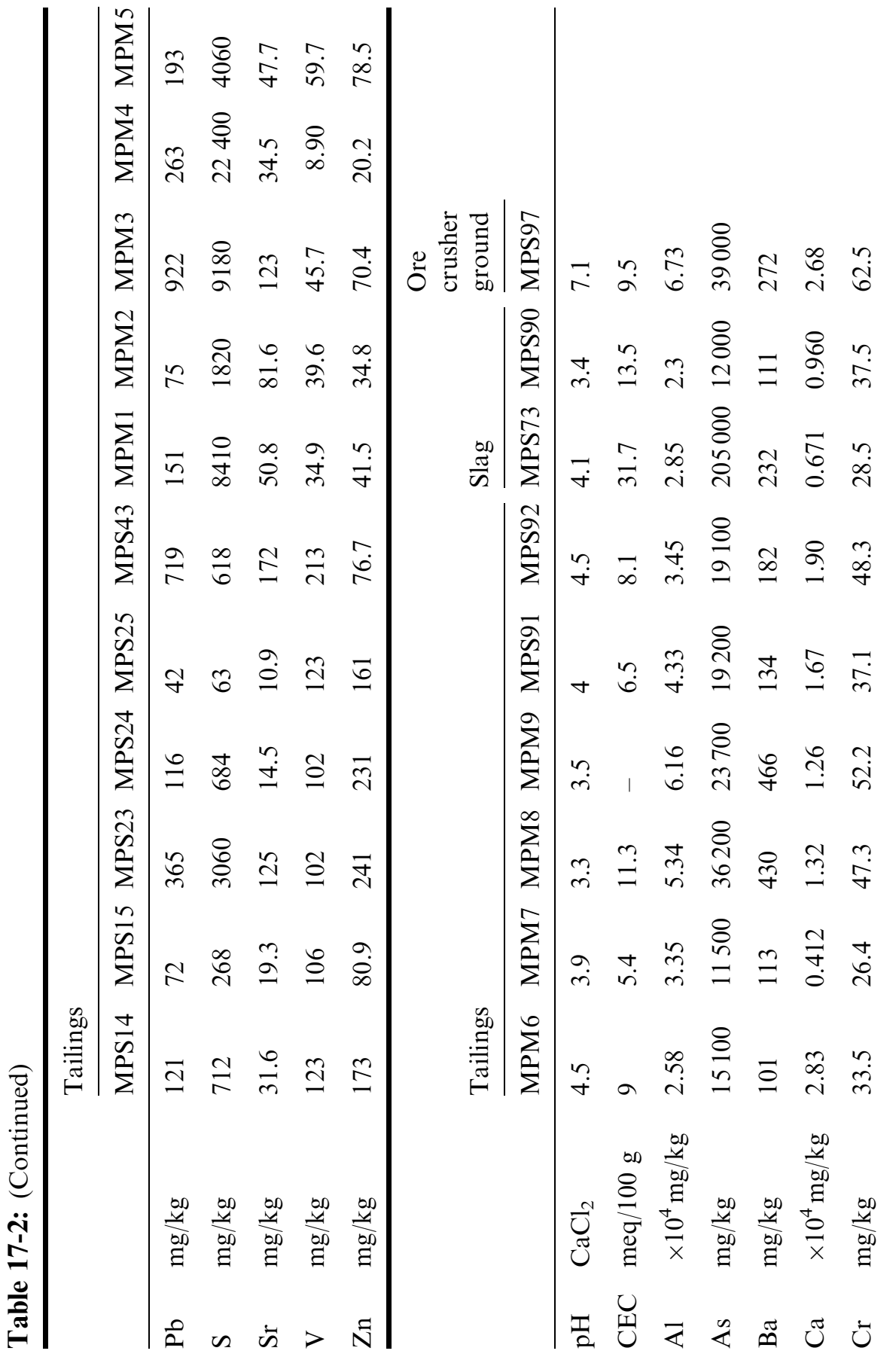




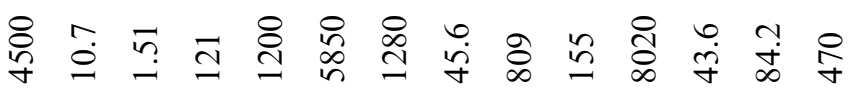

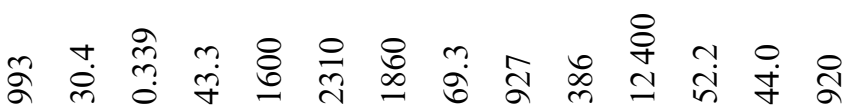

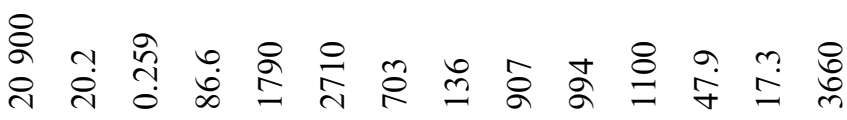

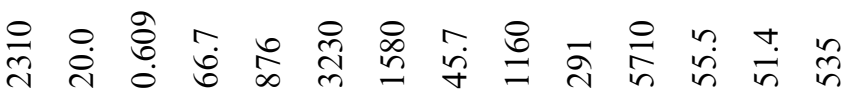

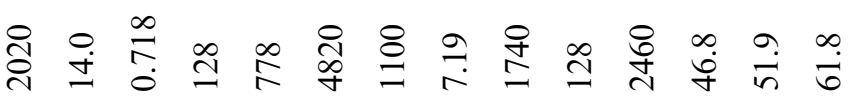

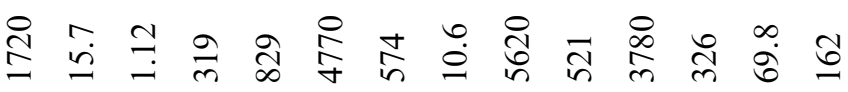

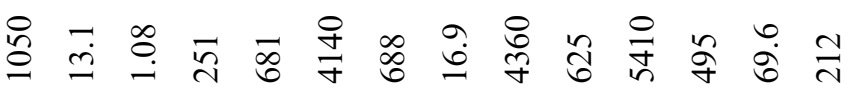

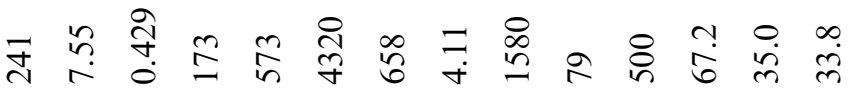

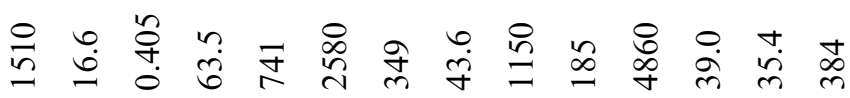

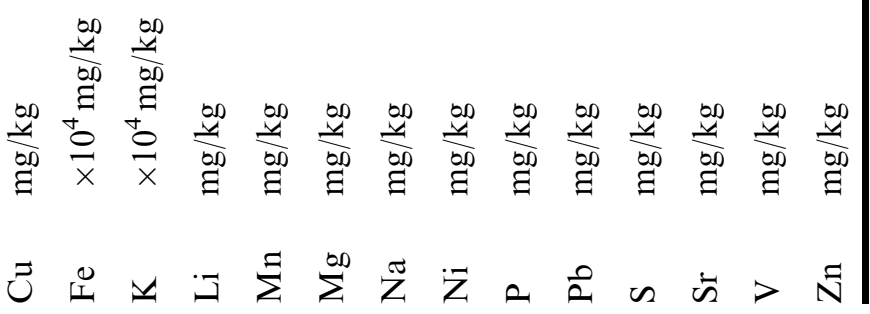


detection limit of XRD analysis $(\sim 5 \%)$ negates the detection of As secondary minerals. Scanning electron microscopy analysis identifies largely angular fragments of quartz, rock fragments composed dominantly of illite, illitequartz or illite-quartz-chlorite-feldspar (possibly pelite or slate). Most of the illitic and chloritic rock fragments (which may also include sericitic fragments) are heavily impregnated or partially replaced by very fine iron oxyhydroxides. Fragments of partially altered hydrothermal mineralisation containing arsenopyrite, often associated with quartz and siderite, are common minor constituents. Some of the arsenopyrite are fresh; but it commonly displays partial alteration to iron oxyhydroxides. Altered pyrite (partially replaced by fine gel-like iron oxyhydroxide) and pyrite-quartz fragments are also present but are much less abundant than arsenopyrite. Small cassiterite grains are present in trace amounts. All of the rock and mineral fragments are coated with a thin film of iron oxyhydroxide (Fig. 17-2) that may be up to $50 \mu \mathrm{m}$ thick. This oxide also forms delicate arcuate structures that bridge pore throats between adjacent grains, weakly cementing the tailings particles. It appears to have been formed by precipitation of the iron oxyhydroxide within, or on, meniscus films of water between adjacent grains, indicating formation within the tailings under partially saturated groundwater conditions (i.e. capillary pore water). The iron oxyhydroxide films have finely banded colloform texture, and often display shrinkage cracks indicating that they may have been quite a hydrous gel originally. Semi-quantitative EDXA also indicates that the iron oxyhydroxide grain-coating cement usually contains a small amount of As, typically between $<0.5 \%$ and $3 \% \mathrm{As}_{2} \mathrm{O}_{3}$.

\section{Black furnace slag}

Scanning electron microscopy analysis of the black slag shows that the material is composed mainly of sand- to gravel-sized fragments of ash or slag, altered illite-quartz slate or pelite rock fragments, rock fragments heavily mineralised (or replaced) by hematite and/or iron oxyhydroxide, fragments of intergrown quartz and hematite/iron oxyhydroxide mineralisation (possibly gossan material), and simple quartz fragments. Minor amounts of altered tin mineralisation are also present. The ash or slag fragments are composed of highly microporous glassy material with globular pores or vesicles, which are impregnated and lined by films of iron oxyhydroxide (Fig. 17-2). Detailed BSEM observations show that the iron-rich coatings have a complex microfabric. They consist mainly of an earlier layer of finely banded colloform iron oxyhydroxide, which rests directly on the grain surfaces, or lines pores and dissolution cavities. It typically displays irregular shrinkage microfractures, 

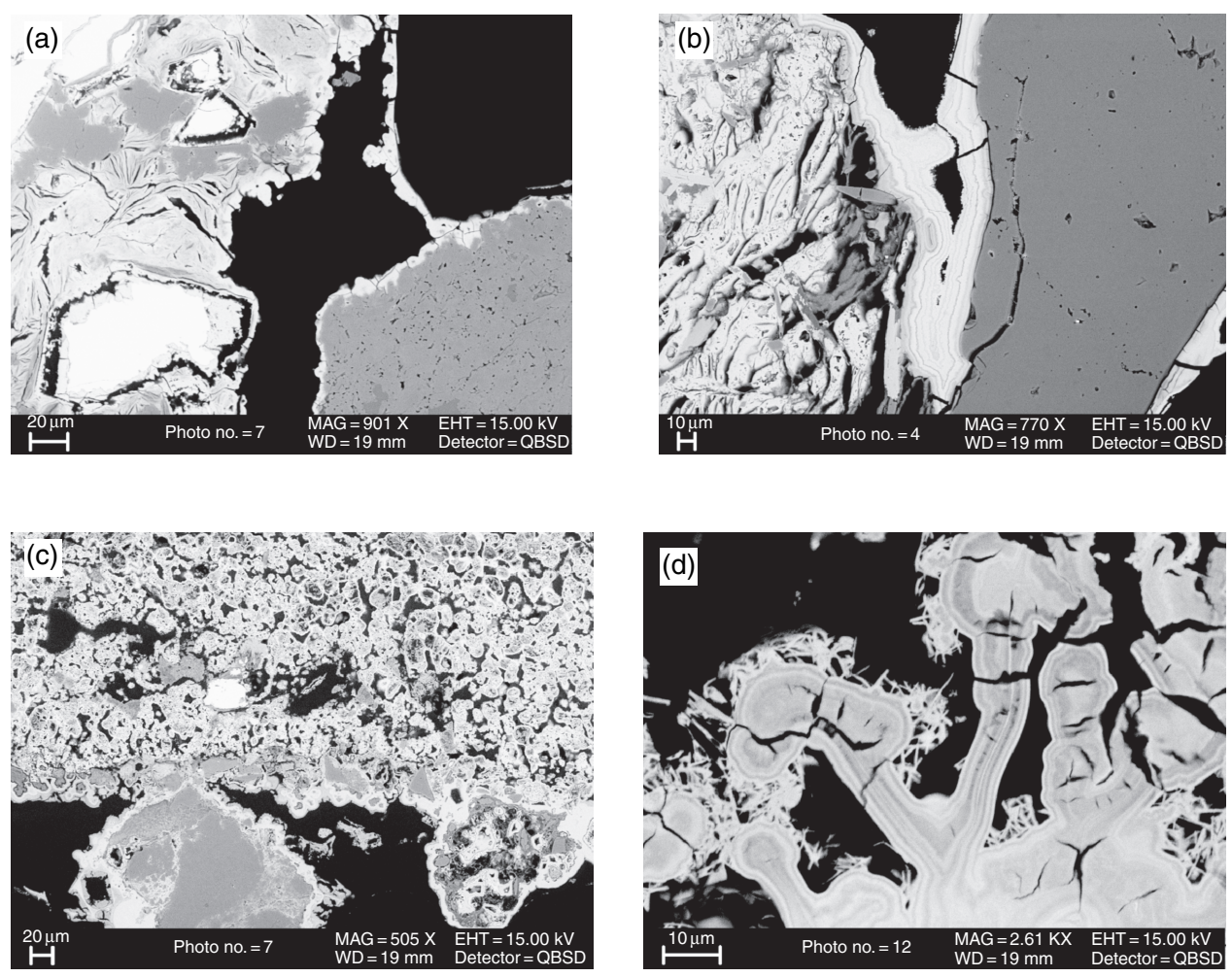

Fig. 17-2: (a) Sample of tailings. Backscattered scanning electron microscopy image showing relict arsenopyrite (white) directly enclosed by a matrix of gellike As-rich Fe oxyhydroxide (light grey) displaying irregular shrinkage cracks. A slightly brighter, and more As-rich, Fe oxyhydroxide coats the margins of the grain and forms a colloform meniscus cement bridging to, and coating, the adjacent quartz grain (dark grey). (b) Sample of tailings. Details of colloform banding within meniscus iron oxyhydroxide cement coating ferruginous micaceous and quartz grains (dark grey). (c) Sample of black slag. Backscattered scanning electron microscopy image showing detail of a microporous altered vesicular glassy slag fragment, with thin bright fringes of $\mathrm{Fe}$ oxyhydroxide lining vesicular cavities. A very bright relict of cassiterite can be seen within the ash fragment. A thin later layer of gel-like or colloform $\mathrm{Fe}$ oxyhydroxide coats the outer edge of the grain. (d) Sample of black slag. Detail of As-rich Fe oxyhydroxide cement coating the surfaces of altered waste fragments. It shows banded colloform oxyhydroxide gel material displaying shrinkage (desiccation) cracks. This is encrusted by more crystalline acicular oxyhydroxide 
indicating that it was originally hydrous. This shrinkage may have taken place as a result of the sample drying out during collection and subsequent thinsection preparation. A later generation of more crystalline iron oxyhydroxide forms an outer coating of fine needle-like crystals resting on the colloform iron oxyhydroxide. EDXA observations indicate that the iron oxyhydroxide usually contains several percent of silica. It can also be As-rich, varying in composition from $<0.5 \% \mathrm{As}_{2} \mathrm{O}_{3}$ up to approximately $30 \% \mathrm{As}_{2} \mathrm{O}_{3}$ (based on semi-quantitative EDXA observations).

\section{Ore crusher area}

Backscattered scanning electron microscopy analysis of the material adjacent to the ore crusher shows common arsenopyrite grains. A secondary phase composed of iron, arsenic and calcium often rims the sulphide grains. Semiquantitative EDXA also indicates that the grain-coating cement usually contains high As, typically between $24 \%$ and $45 \% \mathrm{As}_{2} \mathrm{O}_{3}$, high iron, between $41 \%$ and $47 \% \mathrm{Fe}_{2} \mathrm{O}_{3}$ and minor calcium, between $3 \%$ and $9 \% \mathrm{CaO}$. Discrete, sand-sized, white aggregates, commonly observed in the waste, show the same composition. Fe/As molar ratios between 1 and 1.5 are indicative of arsenate minerals, while $\mathrm{Fe} / \mathrm{As}$ molar ratios greater than 1.5 are considered to be Asrich iron oxyhydroxides (Paktunc et al., 2004). The Fe/As and $\mathrm{Ca} / \mathrm{As}$ molar ratios of the analysed grains of $\sim 1.4$ and 0.4 , respectively, point towards calcium-iron arsenate compositions. Presence of arsenolite $\left(\mathrm{As}_{2} \mathrm{O}_{3}\right)$ is also found.

\section{Efflorescences}

The white-pink efflorescent masses found on the brickwork at the furnace site are made of microcrystalline gypsum (XRD analysis). Intimate association of gypsum $\left(\mathrm{CaSO}_{4} \cdot 2 \mathrm{H}_{2} \mathrm{O}\right)$ and $\mathrm{As}$ is evidenced by SEM-EDXA, possibly as amorphous calcium arsenate coatings or as solid-solution/coprecipitates with gypsum.

\subsubsection{Arsenic partitioning by sequential extractions}

The black slag material MPS90, the sandy tailings sample MPS91 and the sample from the ore crusher area MPS97 were chemically extracted using increasing concentrations of $\mathrm{HNO}_{3}$, followed by ICP-AES analysis of the major and trace elements of the extract. In order to identify the solid-phase partitioning of As, the data were subjected to the CISED chemometric 
data-processing procedure as described in section 17.2. The CISED extraction methodology and associated data processing identifies a number of different, geochemically distinct, components for each sample, named on the basis of the prevailing elemental composition. The following outputs from processing the CISED extraction data were generated: a series of extraction profiles of the total mass of extracted elements against reagent concentration (steps 1-14) (Fig. 17-3) for each sample (one profile for each identified component); a table of the elemental composition of each identified component (Table 17-3), and information relating to the distribution of As determined within each identified component (Fig. 17-4).

In all samples, the component which makes up the most significant percentage of the total extract contains mainly iron (Fig. 17-3). The elemental composition of this component shown in Table 17-3 corresponds to iron oxyhydroxide phases, which can contain variable minor amounts of calcium, arsenic, sulphur, silicon and aluminium (Paktunc et al., 2004). This main component is extracted over the range $0.5-5 \mathrm{M} \mathrm{HNO}_{3}$ (steps 9-14) with more defined windows of extraction at $0.5 \mathrm{M} \mathrm{HNO}_{3}$ and $5 \mathrm{M}$ $\mathrm{HNO}_{3}$ (Fig. 17-3). These iron-dominated components are always the phases where As is mainly partitioned (Fig. 17-4). In particular, in the sandy tailings and the black slag, two iron-rich components are identified, one iron-dominated and with high As content (extracted at $5 \mathrm{M} \mathrm{HNO}_{3}$ ) and another one richer in calcium and lower in arsenic, which is leached at an earlier stage in the extraction $\left(0.1-0.5 \mathrm{M} \mathrm{HNO}_{3}\right)$. The degree of iron oxyhydroxide crystallinity and trace element content are both factors consistent with observed different mineral dissolution rates in the acid extracts. Accordingly, the CISED extraction profiles confirm the coexistence of various As-bearing iron phases, as shown by SEM observations. In the ore crusher area, As is more evenly partitioned. Of particular note is an identifiable water soluble component, which releases more than $1000 \mathrm{mg} / \mathrm{kg}$ of As ( $4 \%$ of the original As content). A component made of $78 \%$ calcium and $12 \%$ arsenic is also identified with a diffuse window of extraction in the range $0.01-0.5 \mathrm{M} \mathrm{HNO}_{3}$ in this material.

\subsubsection{Arsenic speciation by X-ray absorption spectroscopy}

\section{$X$-ray absorption near edge structure spectra}

X-ray absorption near edge structure (XANES) spectra collected from a selection of mine tailings and slag material are shown in Fig. 17-5. The position and shape of the spectra are all very similar and consistent with an 

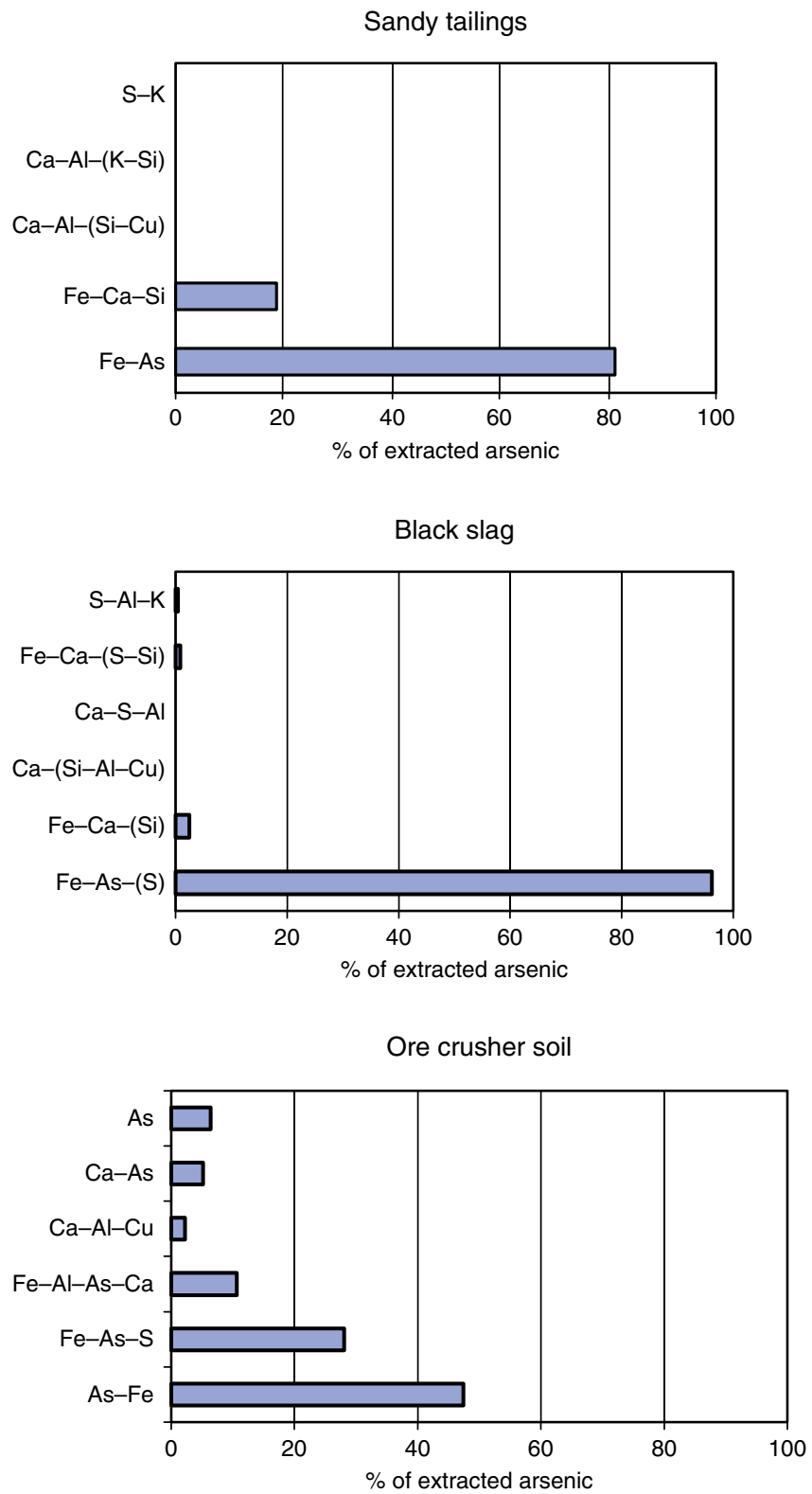

Fig. 17-3: Relative distribution of As in the CISED-extracted physico-chemical components 
Table 17-3: Chemical composition (\%) of the CISED physico-chemical components

\begin{tabular}{|c|c|c|c|c|c|}
\hline \multicolumn{6}{|c|}{ Sandy tailings (MPS91) } \\
\hline & $\mathrm{Fe}-\mathrm{As}$ & $\mathrm{Fe}-\mathrm{Ca}-\mathrm{Si}$ & $\mathrm{Ca}-\mathrm{Al}-(\mathrm{Si}-\mathrm{Cu})$ & S-K & $\mathrm{Ca}-\mathrm{Al}-(\mathrm{K}-\mathrm{Si})$ \\
\hline $\mathrm{Al}$ & 6.71 & 3.96 & 15.4 & 2.78 & 14.3 \\
\hline As & 18.6 & 7.80 & 0.00 & 0.00 & 0.00 \\
\hline $\mathrm{Ba}$ & 0.00 & 0.00 & 0.62 & 0.00 & 0.00 \\
\hline $\mathrm{Ca}$ & 1.34 & 35.1 & 69.9 & 0.00 & 59.9 \\
\hline $\mathrm{Cd}$ & 0.00 & 0.00 & 0.00 & 0.00 & 0.00 \\
\hline $\mathrm{Co}$ & 0.00 & 0.00 & 0.00 & 0.02 & 0.02 \\
\hline $\mathrm{Cr}$ & 0.01 & 0.01 & 0.01 & 0.00 & 0.00 \\
\hline $\mathrm{Cu}$ & 0.04 & 1.96 & 4.99 & 0.00 & 4.20 \\
\hline $\mathrm{Fe}$ & 69.6 & 37.2 & 0.00 & 0.00 & 0.00 \\
\hline $\mathrm{K}$ & 0.22 & 0.00 & 2.50 & 25.8 & 8.21 \\
\hline $\mathrm{Li}$ & 0.03 & 0.01 & 0.04 & 0.43 & 0.11 \\
\hline $\mathrm{Mg}$ & 1.42 & 0.62 & 0.49 & 8.82 & 4.32 \\
\hline $\mathrm{Mn}$ & 0.33 & 0.35 & 0.16 & 0.34 & 0.84 \\
\hline $\mathrm{Na}$ & 0.00 & 0.00 & 0.14 & 3.60 & 0.37 \\
\hline $\mathrm{Ni}$ & 0.00 & 0.01 & 0.00 & 0.01 & 0.02 \\
\hline $\mathrm{P}$ & 0.00 & 3.16 & 0.00 & 0.00 & 0.00 \\
\hline $\mathrm{Pb}$ & 0.03 & 0.08 & 0.08 & 0.00 & 0.00 \\
\hline S & 1.60 & 0.00 & 0.00 & 57.0 & 4.79 \\
\hline $\mathrm{Si}$ & 0.00 & 9.72 & 5.57 & 1.21 & 2.79 \\
\hline $\mathrm{Sr}$ & 0.00 & 0.01 & 0.07 & 0.01 & 0.07 \\
\hline V & 0.01 & 0.01 & 0.00 & 0.00 & 0.00 \\
\hline $\mathrm{Zn}$ & 0.01 & 0.03 & 0.03 & 0.00 & 0.07 \\
\hline
\end{tabular}


Table 17-3 (Continued)

\begin{tabular}{|c|c|c|c|c|c|c|}
\hline & $\begin{array}{l}\mathrm{Fe}-\mathrm{As}- \\
(\mathrm{S})\end{array}$ & $\begin{array}{l}\mathrm{Fe}-\mathrm{Ca}- \\
(\mathrm{Si})\end{array}$ & $\mathrm{Ca}-(\mathrm{Si}-\mathrm{Al}-\mathrm{Cu})$ & $\begin{array}{l}\mathrm{Ca}-\mathrm{S}- \\
\mathrm{Al}\end{array}$ & $\mathrm{Fe}-\mathrm{Ca}-(\mathrm{S}-\mathrm{Si})$ & $\begin{array}{l}\mathrm{S}- \\
\mathrm{Al}-\mathrm{K}\end{array}$ \\
\hline $\mathrm{Al}$ & 0.00 & 1.10 & 5.77 & 11.0 & 3.89 & 18.2 \\
\hline As & 9.83 & 0.68 & 0.00 & 0.00 & 0.91 & 0.92 \\
\hline $\mathrm{Ba}$ & 0.09 & 0.21 & 0.00 & 0.00 & 0.22 & 0.00 \\
\hline $\mathrm{Ca}$ & 0.00 & 34.1 & 79.0 & 36.0 & 17.8 & 0.00 \\
\hline $\mathrm{Cd}$ & 0.00 & 0.00 & 0.00 & 0.00 & 0.00 & 0.00 \\
\hline Co & 0.00 & 0.00 & 0.00 & 0.02 & 0.00 & 0.15 \\
\hline $\mathrm{Cr}$ & 0.01 & 0.01 & 0.01 & 0.00 & 0.00 & 0.01 \\
\hline $\mathrm{Cu}$ & 0.00 & 0.11 & 4.92 & 0.00 & 1.11 & 1.17 \\
\hline $\mathrm{Fe}$ & 77.6 & 51.1 & 0.99 & 0.00 & 56.9 & 0.00 \\
\hline K & 0.65 & 0.42 & 1.36 & 8.22 & 3.44 & 14.5 \\
\hline $\mathrm{Li}$ & 0.00 & 0.00 & 0.01 & 0.04 & 0.00 & 0.03 \\
\hline $\mathrm{Mg}$ & 0.08 & 0.24 & 0.23 & 2.57 & 0.01 & 1.76 \\
\hline Mn & 0.03 & 0.00 & 0.17 & 0.56 & 0.19 & 2.79 \\
\hline $\mathrm{Na}$ & 0.16 & 0.00 & 0.00 & 3.33 & 0.51 & 2.83 \\
\hline $\mathrm{Ni}$ & 0.00 & 0.00 & 0.01 & 0.02 & 0.00 & 0.08 \\
\hline $\mathrm{P}$ & 1.13 & 0.49 & 0.54 & 1.52 & 0.00 & 0.00 \\
\hline $\mathrm{Pb}$ & 0.36 & 0.05 & 0.04 & 0.22 & 0.01 & 0.00 \\
\hline $\mathrm{S}$ & 9.31 & 2.70 & 0.00 & 31.5 & 8.95 & 56.2 \\
\hline $\mathrm{Se}$ & 0.00 & 0.00 & 0.00 & 0.00 & 0.01 & 0.02 \\
\hline $\mathrm{Si}$ & 0.71 & 8.71 & 6.63 & 4.94 & 6.06 & 0.00 \\
\hline $\mathrm{Sr}$ & 0.02 & 0.00 & 0.17 & 0.01 & 0.08 & 0.47 \\
\hline V & 0.01 & 0.01 & 0.00 & 0.01 & 0.00 & 0.00 \\
\hline $\mathrm{Zn}$ & 0.05 & 0.01 & 0.18 & 0.07 & 0.01 & 0.86 \\
\hline
\end{tabular}


Table 17-3: (Continued)

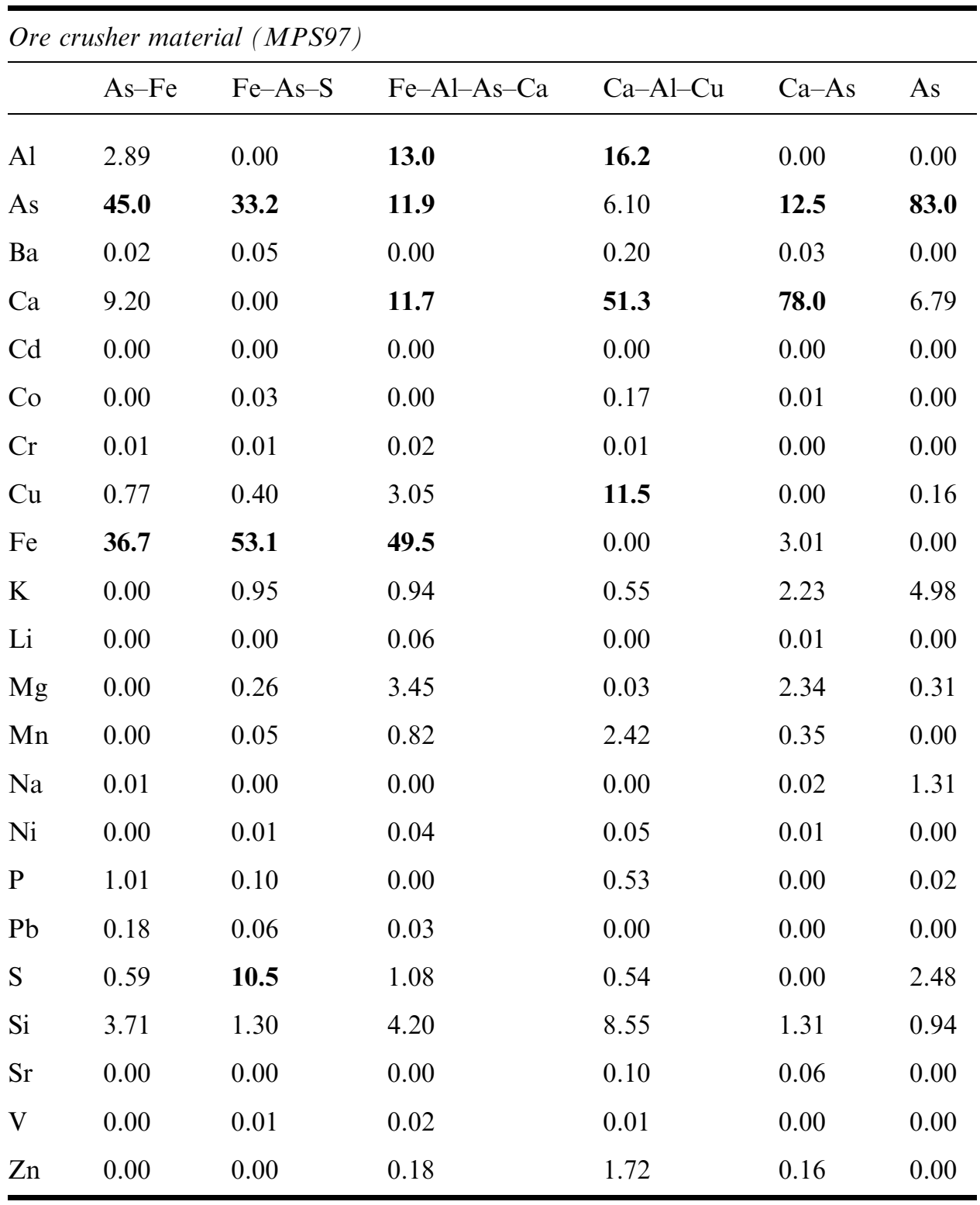

The components are reported in order of decreasing amount of soil extracted in $\mathrm{mg} / \mathrm{kg}$. In bold, elements that contribute more than $10 \%$ by weight to the composition of the components. 


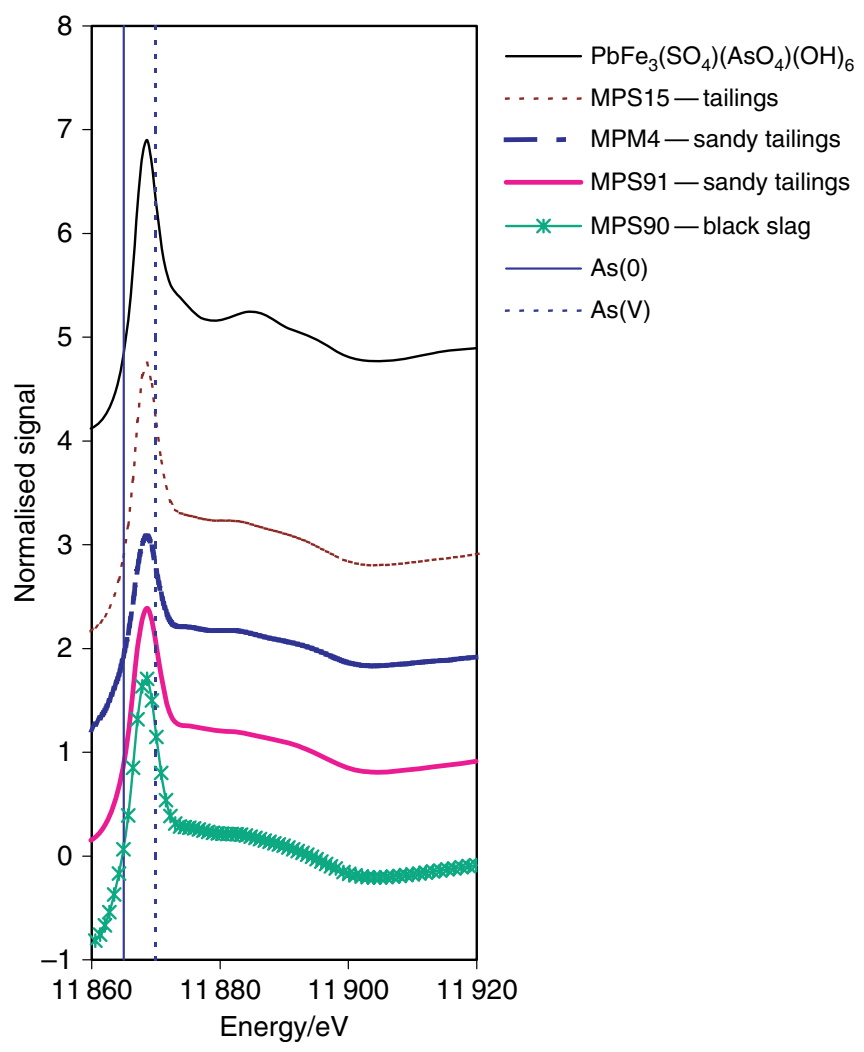

Fig. 17-4: X-ray absorption near edge structure spectra of a selection of mine wastes. A model compound $\mathrm{PbFe}_{3}\left(\mathrm{SO}_{4}\right)\left(\mathrm{AsO}_{4}\right)(\mathrm{OH})_{6}$ is included. The vertical lines show the theoretical absorption edge position for $\operatorname{As}(0)$ $(11865 \mathrm{eV})$ and $\mathrm{As}(\mathrm{V})(11870 \mathrm{eV})$

arsenate species $[\mathrm{As}(\mathrm{V})$ tetrahedrally surrounded by four oxygen atoms]. The compound $\mathrm{PbFe}_{3}\left(\mathrm{SO}_{4}\right)\left(\mathrm{AsO}_{4}\right)(\mathrm{OH})_{6}$ was used as an arsenate standard and has the same shaped XANES as the samples tested.

\section{Extended X-ray absorption fine structure spectra}

Extended X-ray absorption fine structure spectroscopy has been used to complement the chemical sequential extraction procedure in order to evaluate the speciation of As in the samples. Quantitative fits of EXAFS spectra using 


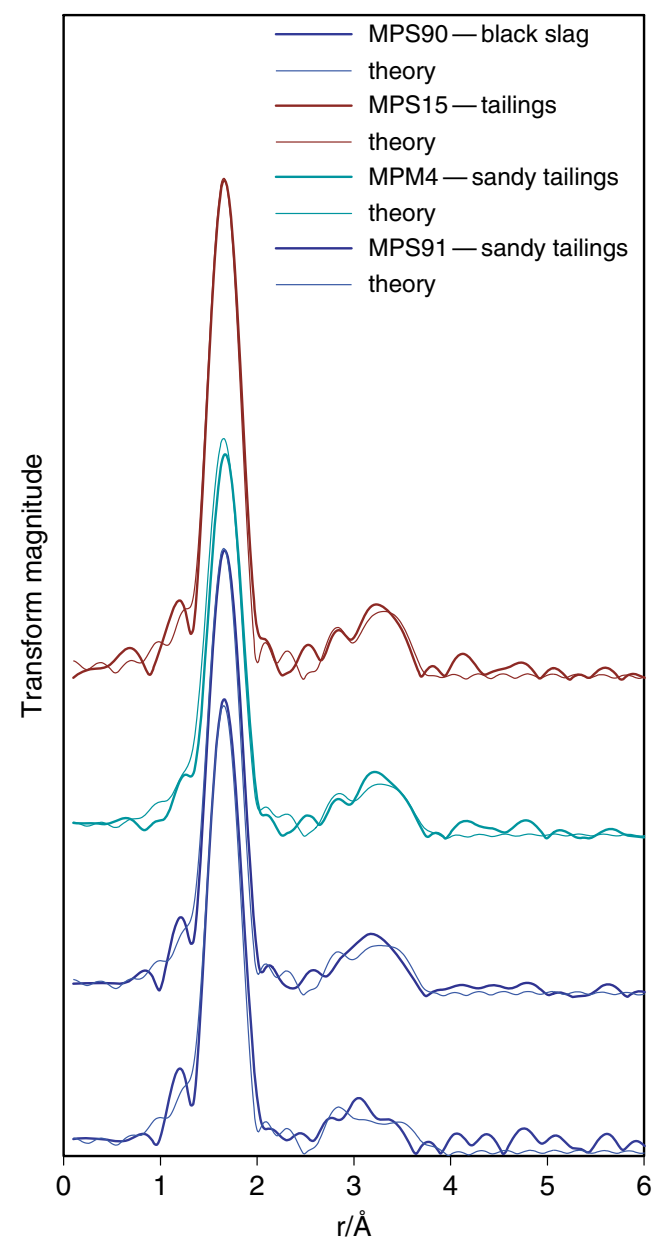

Fig. 17-5: Radial structure functions for a selection of mine wastes. Solid line: experimental data, dashed line: least-squares fit using parameters shown in Table 17-4

theoretical standards enable the determination of the nearest-neighbour atoms and approximate coordination numbers and inter-atomic bond distances. The first peak in the Fourier transforms yields information on the AU3 As-O relationship. In all cases, the main contribution to the EXAFS is due to AU4 the four oxygen atoms at a distance of ca. $1.68 \AA$ (Fig. 17-6). There is no evidence in any spectrum of contributions from sulphur or iron at ca. 2.2-2.3 $\AA$, which 
would be characteristic of arsenopyrite. There are outer shells evident in all the Fourier transforms. In most cases, the EXAFS oscillations giving rise to these could be fitted using silicon, arsenic or iron backscatterers. However, iron at ca. $2.86 \AA$ usually gave the best fit and the fit was usually improved further by addition of a second shell of iron at ca. $3.34 \AA$. These results imply either adsorption of the As onto an iron oxyhydroxide substrate or incorporation of the As into a mixed metal oxide phase. Previous EXAFS spectroscopy study by Foster et al. (1998), Randall et al. (2001) and Savage et al. (2000) indicated arsenate tetrahedra sorbed onto the fine-grained iron-rich weathering products of As mine tailings. The two different As-Fe distances may reflect the presence of doubly oxo-bridged and singly oxo-bridged species. Table 17-4 lists the parameters of the best fits.

No indication of the presence of As bound in arsenopyrite or arsenical pyrite seems to contradict the findings from SEM observations. However, EXAFS analysis of heterogeneous materials is complicated by the presence of overlapping peaks, multi-atom shells and increased disorder due to the presence of poorly crystalline phases (Foster et al., 1998); and lack of sensitivity to minor forms of an element is a major obstacle using EXAFS (Isaure et al., 2002). The EXAFS signal is a weighted average of all chemical species of an element and the ability to discriminate between multiple element forms depends on their relative abundance.

Table 17-4: Best-fit parameters for the As K-edge EXAFS spectra

\begin{tabular}{llllll}
\hline Sample & Scatterer & $N$ & $r(\AA)$ & $2 \sigma^{2}\left(\AA^{2}\right)$ & $R$-factor \\
\hline MPS90 & $\mathrm{O}$ & 4 & 1.69 & 0.006 & 23 \\
& $\mathrm{Fe}$ & 2 & 2.85 & 0.033 & \\
\multirow{2}{*}{ MPS91 } & $\mathrm{Fe}$ & 1 & 3.37 & 0.017 & \\
& $\mathrm{O}$ & 4 & 1.69 & 0.006 & 22 \\
& $\mathrm{Fe}$ & 2 & 2.86 & 0.035 & \\
MPM4 & $\mathrm{Fe}$ & 1 & 3.33 & 0.011 & \\
& $\mathrm{O}$ & 4 & 1.69 & 0.007 & 26 \\
& $\mathrm{Fe}$ & 2 & 2.85 & 0.035 & \\
MPS15 & $\mathrm{Fe}$ & 1 & 3.33 & 0.011 & \\
& $\mathrm{O}$ & 4 & 1.69 & 0.004 & 21 \\
& $\mathrm{Fe}$ & 2 & 2.85 & 0.032 & \\
\hline
\end{tabular}




\subsubsection{Arsenic in water leachates}

The first two steps of the sequential extraction using DIW as the leaching agent represent a fraction subject to instantaneous dissolution/desorption upon wetting. This fraction gives an indication of the potential mobility of As in the studied material. The results for a selection of samples are reported in Table 17-5.

The DIW leaching, defined in terms of release of the element per kilogram of material, varies widely from 0.1 to $1440 \mathrm{mg} / \mathrm{kg}$ As (Table 17-5). In percentage terms, the total As content ranges from $0.0004 \%$ to $3.70 \%$, with the highest leachability in the ore crusher area material (MPS97) and the lowest in the sandy tailings (MPM1-MPM4-MPM9). This is despite the comparable total As concentration.

\subsubsection{Thermodynamic calculations}

The saturation indices (SI) of the DIW leachates with respect to arsenates, iron and aluminium oxyhydroxides and sulphates were calculated using PHREEQC (Parkhurst, 1995) and measured $\mathrm{pH}$, Eh and temperature data (Table 17-6). Based on the available thermodynamic data, the DIW leachate solutions are undersaturated with respect to all arsenate phases, i.e. there is not an arsenate mineral which controls the concentration of dissolved As in the leachates of the tailings and slag. Goethite is slightly supersaturated, suggesting dissolution of iron oxyhydroxides as the controlling phase on As in the leachates through dissolution/desorption. In contrast, in response to the higher $\mathrm{pH}$, the leachates of the ore crusher material are supersaturated in weillite, scorodite and arsenate phases of copper, calcium-copper and aluminium (Table 17-6), as well as in goethite and $\mathrm{Fe}(\mathrm{OH})_{3(\mathrm{a})}$, which all contribute to dissolved As. Arsenolite is strongly undersaturated in the ore crusher material leachate. However, it is important to point out that the speciation model calculates saturation indices based on chemical equilibrium between minerals and water and assumes very fast reactions. Speciation calculations are complicated by uncertainty in the values of thermodynamic constants for mineral phases, as only pure phases are considered in the available databases and equilibrium constants of naturally occurring solidsolutions may differ significantly from these values (Sracek et al., 2004). Nevertheless, the model gives useful information on the possible suite of mineral phases controlling As in solution under certain defined physicochemical conditions. 


\begin{tabular}{|c|c|c|c|}
\hline 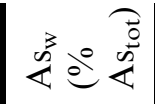 & 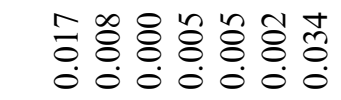 & $\begin{array}{l}\text { ปे } \\
\text { స̃ } \\
0\end{array}$ & $\stackrel{r}{i}$ \\
\hline 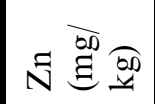 & ̦ㅟำ & $\begin{array}{l}\overline{0} \infty \\
\dot{\sigma} \infty \\
\dot{\sigma}\end{array}$ & $\stackrel{2}{0}$ \\
\hline 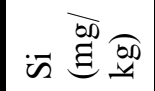 & 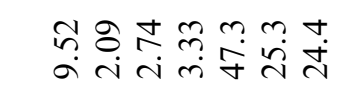 & $\bar{n}$ ñ & $\stackrel{\infty}{\sim}$ \\
\hline 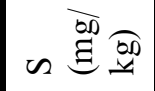 & 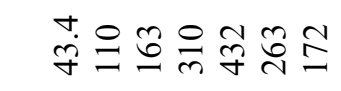 & $\begin{array}{l}\infty \\
\infty \\
i \\
i\end{array}$ & 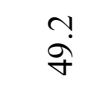 \\
\hline 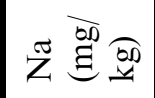 & 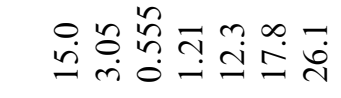 & $\hat{\vartheta} \underset{\dot{v}}{\stackrel{\infty}{+}}$ & $\stackrel{0}{i}$ \\
\hline 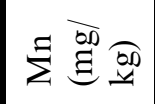 & 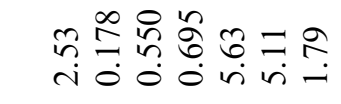 & $\ddot{6} \mathfrak{0}$ & $\frac{2}{\stackrel{0}{0}}$ \\
\hline$\sum^{\infty} \stackrel{\infty}{\Xi} \underset{\Xi 0}{\infty}$ & 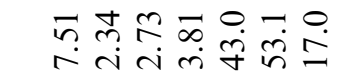 & $\begin{array}{l}\hat{\sigma} \\
\dot{\sigma}\end{array}$ & $\vec{a}$ \\
\hline 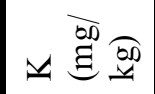 & 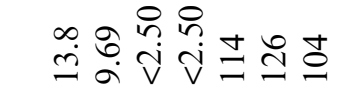 & 商㠻 & ã \\
\hline 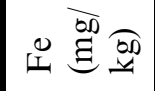 & 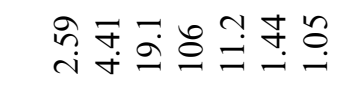 & 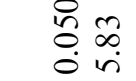 & $\stackrel{\vec{p}}{\stackrel{0}{0}}$ \\
\hline 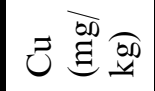 & î̃ & $\underset{\infty}{n} \frac{n}{\pi}$ & ஸे \\
\hline 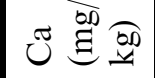 & 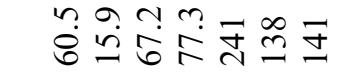 & भ̊ ते & ஜิ \\
\hline$\sum \stackrel{000}{D^{200}}$ & 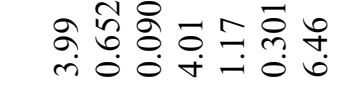 & gे ố & : \\
\hline 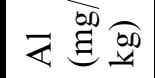 & 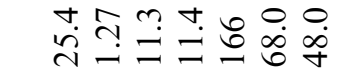 & 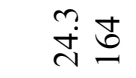 & 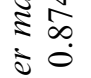 \\
\hline & 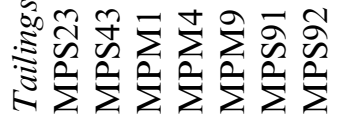 & 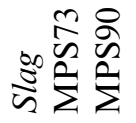 & 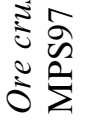 \\
\hline
\end{tabular}




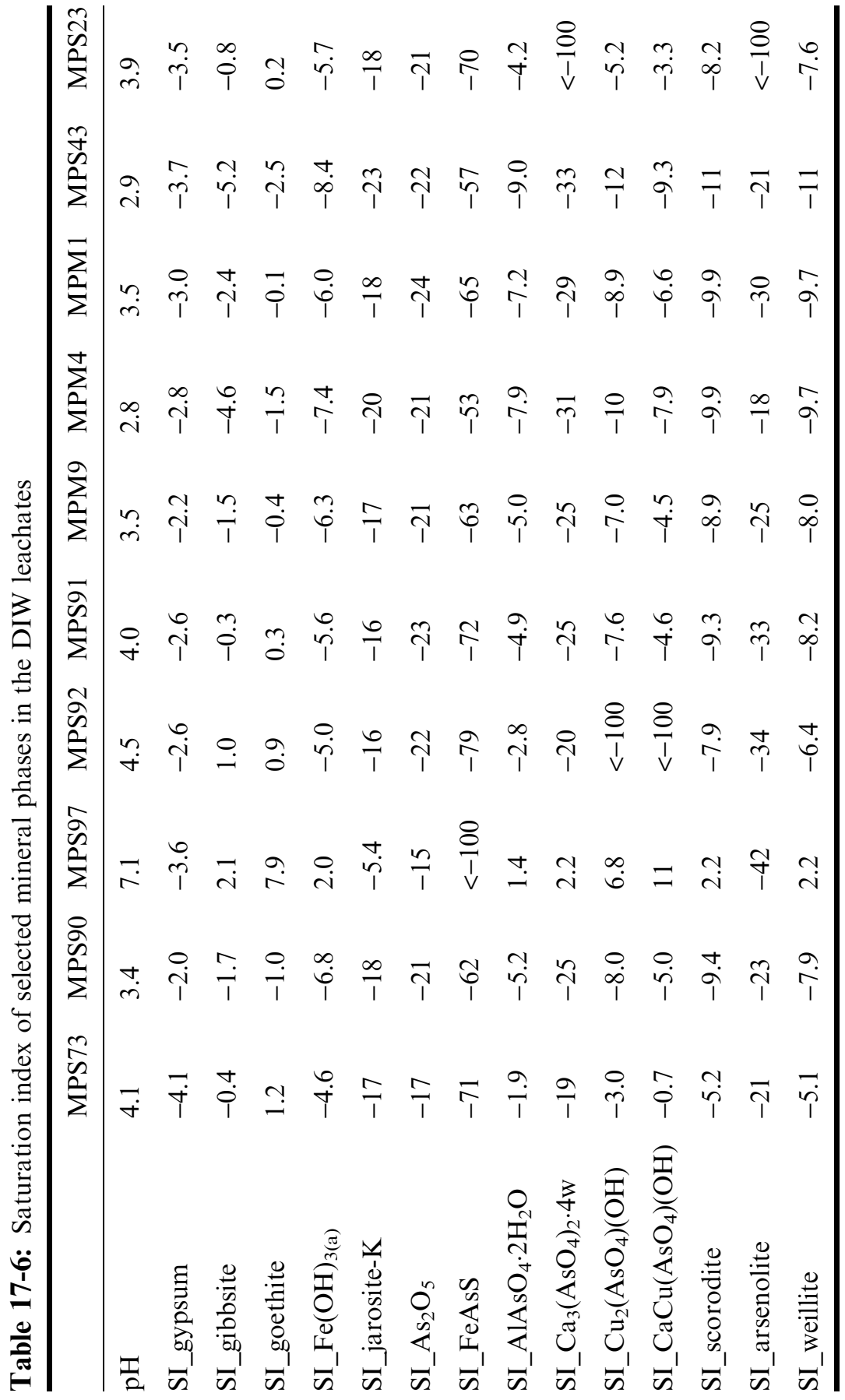




\subsection{Geochemical controls on As mobilisation}

Iron oxyhydroxides are the most significant As carriers in the mine wastes from Devon Great Consols Mine. Petrographic evidence suggests iron oxyhydroxide films with variable As content precipitating from pore water solutions circulating in the tailings and waste tips. In addition, As occurs in calcium-iron arsenates rimming ore particles in the ore crusher material and calcium arsenates in efflorescences extensively covering the calciner brickwork. In the first two DIW CISED extractions, low As solubility as a percentage of total As was measured in the mine wastes. This indicates the role of the iron oxyhydroxides as stable As binding phases in an oxidising acid environment, as well documented by many authors (Bowell et al., 1994; Garcia-Sanchez et al., 2002). However, higher As release was measured in the ore crusher sample with $\mathrm{pH} 7$ and an ironcalcium-arsenic association. Neutral-alkaline conditions promote desorption of As bound to iron oxyhydroxides (Pierce and Moore, 1982) as well as dissolution of thermodynamically unstable iron and calcium arsenate minerals (Dove and Rimstidt, 1985; Paktunc et al., 2004). Arsenate mineral solubilities increase from ferric arsenates to calcium arsenates (Rochette et al., 1998; Paktunc et al., 2003). Both factors might account for the higher As release from the crusher material.

\subsection{Future directions}

The complementary use of SEM, X-ray absorption spectroscopy (XAS) analysis and sequential chemical extraction methods discussed in this work have proved to constitute a useful tool to determine As solid-phase speciation and to evaluate the geochemical controls on As mobility. This information is critical for risk assessment and management of As-contaminated environment. As analytical techniques improve and are made more available, more comprehensive approaches in the characterisation of mine waste are envisaged. Further work on this basis will contribute to the development of best waste-management practices for mine sites.

\section{Acknowledgements}

This study is published with the permission of the Director, British Geological Survey (NERC). Grateful acknowledgements are due to Fariba Bahrami (Daresbury) for the provision of beam time and John Charnock (Daresbury) 
for the interpretation of XAS spectra. Antoni Miladoswki is especially acknowledged for the SEM work. The authors would like to extend particular thanks to Mr M. Snelgrove, Tavistoch Woodland Manager, for allowing access to Devon Great Consols Mine.

\section{References}

Abrahams, P. W., Thornton, I. (1987) Distribution and extent of land contaminated by As and associated metals in mining regions of south-west England. Transactions of the Institute of Mining and Metallurgy B, 1-8.

Aston, S. R., Thornton, I., Webb, J. S. (1975) Arsenic in stream sediments and waters of South West England. The Science of Total Environment 4, 347-358.

Ball, J. W., Nordstrom, D. K. (1991) User's manual for WATEQ4F, with revised thermodynamic data base and test cases for calculating speciation of major, trace, and redox elements in natural waters. U.S. Geological Survey Open-File Report, 91-183.

Binsted, N. (1998) Daresbury Laboratory EXCURV98 Program.

Binsted, N., Strange, R. W., Hasnain, S. S. (1992) Constrained and restrained refinement in EXAFS data analysis with curved wave theory. Biochemistry 31, 12117-12125.

Bowell, R. J., Morley, N. H., Din, V. K. (1994) Arsenic speciation in soil porewaters from the Ashanti Mine, Ghana. Applied Geochemistry 9, 15-22.

Cave, M. R., Milodowski, A. E., Friel, E. N. (2004) Evaluation of a method for identification of host physico-chemical phases for trace metals and measurement of their solid-phase partitioning in soil samples by nitric acid extraction and chemometric mixture resolution. Geochemistry: Exploration, Environment, Analysis 4, 71-86.

Colbourn, P., Alloway, B. J., Thornton, I. (1975) Arsenic and heavy metals in soils associated with regional geochemical anomalies in south-west England. The Science of the Total Environment 4, 359-363.

Dines, H. G. (1956) The Metalliferous Mining Region of South-West England (1st edition). Memoirs of the Geological Survey of Great Britain. London: HMSO. ISBN 118800663.

Dove, P. M., Rimstidt, J. D. (1985) The solubility and stability of scodorite. American Mineralogist 70, 838-844.

Foster, A. L., Brown, G. E., Tingle, T. N., et al. (1998) Quantitative As speciation in mine tailings using X-ray absorption spectroscopy. American Mineralogist 83, $553-568$.

Garcia-Sanchez, A., Alvarez-Ayuso, E., Rodriguez-Martin, F. (2002) Sorption of $\mathrm{As}(\mathrm{V})$ by some oxyhydroxides and clay minerals. Application to its immobilization in two polluted mining soils. Clay Minerals 37, 187-194. 
Gaskova, O., Azaroual, M., Piantone, P., et al. (2001) Arsenic behaviour in subsurface hydrogeological systems - a critical review of thermodynamic data for arsenic minerals and aqueous species - a compilation of arsenic surface complexation reactions. BRGM, BRGM/RP-51356-FR.

Gurman, S. J., Binsted, N., Ross, I. (1984) A rapid, exact curved-wave theory for EXAFS calculations. Journal of Physical Chemistry 17, 143-151.

Hedin, L., Lundqvist, S. (1969) Effects of electron-electron and electron-phonon interactions on the one-electron states of solids. Solid State Physics 23, 1-181.

Isaure, M., Laboudigue, A., Manceau, A., et al. (2002) Quantitative Zn speciation in a contaminated dredged sediment by u-Pixe, u-SXRF, EXAFS spectroscopy and principal component analysis. Geochimica et Cosmochimica Acta 66, 1549-1567.

Juillot, F., Ildefonse, P., Morin, G., et al. (1999) Remobilization of As from buried wastes at an industrial site: mineralogical and geochemical control. Applied

AU7 Geochemistry 14, 1031-1048.

Klinck, B. A., Palumbo, B., Cave, M., et al. (in press) Arsenic dispersal and bioaccessibility in mine contaminated soils: a case study from an abandoned arsenic mine in Devon, UK. British Geological Survey Research Report,

AU8 RR/04/03.

Li, X. D., Coles, B. J., Ramsey, M. H., et al. (1995) Chemical partitioning of the new National Institute of Standards and Technology standard reference materials (Srm-2709-2711) by sequential extraction using inductively-coupled plasmaatomic emission-spectroscopy. Analyst 120(5), 1415-1419.

Mitchell, P., Barr, D. (1995) The nature and significance of public exposure to As: a review of its relevance to South West England. Environmental Geochemistry and Health 17, 57-82.

Paktunc, D., Foster, A., Laflamme, G. (2003) Speciation and characterization of arsenic in Ketza river mine tailings using X-ray absorption spectroscopy. Environmental Science and Technology 37, 2067-2074.

Paktunc, D., Foster, A., Heald, S., et al. (2004) Speciation and characterisation of arsenic in gold ores and cyanidation tailings using X-ray absorption spectroscopy. Geochimica et Cosmochimica Acta 68, 969-983.

Parkhurst, D. L. (1995) User's guide to PHREEQC - a computer program for speciation, reaction-path, advective-transport, and inverse geochemical calculations. U.S. Geological Survey, Water-Resources Investigations Report, 95-4227.

Pierce, M. L., Moore, C. B. (1982) Adsorption of arsenite and arsenate on amorphous iron hydroxide. Water Research 16, 1247-1253.

Pye, A. R., Dixon, T. (1989) The arsenic works at Devon Great Consols Mine, Tavistock. Proceedings of the Devon Archaeology Society 47, 79-111.

Randall, S. R., Sherman, D. M., Ragnarsdottir, K. V. (2001) Sorption of arsenic(V) on green rust $\left(\mathrm{Fe} 4(\mathrm{II}) \mathrm{Fe} 2(\mathrm{III})(\mathrm{OH}) 12 \mathrm{SO}_{4} \cdot 3 \mathrm{H}_{2} \mathrm{O}\right)$ and lepidocrocite $(-\mathrm{FeOOH})$ : surface complexes from EXAFS spectroscopy. Geochimica et Cosmochimica Acta 65, 1015-1023. 
Rochette, E. A., Li, G. C., Fendord, S. E. (1998) Stability of arsenate minerals in soil under biotically generated reducing conditions. Soil Science Society American Journal 62, 1530-1537.

Savage, K. S., Tingle, T. N., O'Day, P. A., et al. (2000) Arsenic speciation in pyrite and secondary weathering phases, Mother Lode Gold District, Tuolumne Country, California. Applied Geochemistry 15, 1219-1244.

Sracek, O., Bhattacharya, P., Jacks, G., et al. (2004) Behaviour of arsenic and geochemical modeling of arsenic enrichment in aqueous environments. Applied Geochemistry 19, 169-180.

Tessier, A., Campbell, P. G. C., Bisson, M. (1979) Sequential extraction procedure for the speciation of particulate trace metals. Analytical Chemistry 51, 844-850. 



\section{Non-print items}

\section{Author Query Form}

First Proof

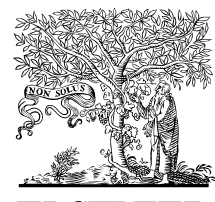

ELSEVIER

Title: Arsenic in Soil and Groundwater Environment

\section{Article: 9017}

Dear Author,

During the preparation of your manuscript for typesetting some questions have arisen. These are listed below. Please check your typeset proof carefully and mark any corrections in the margin of the proof or compile them as a separate list.

\section{Author Queries and/or remarks}

\begin{tabular}{|c|c|}
\hline AU:1 & $\begin{array}{l}\text { Please check the usage of ' } 3 \text { to } 65^{\circ} 2 \theta^{\prime} \text { in sentence 'XRD analysis was } \\
\text { performed from...'. }\end{array}$ \\
\hline AU:2 & $\begin{array}{l}\text { Please check whether the symbol ' }=\text { ' in the equilibrium reactions } \\
\text { should be changed to ' } \rightarrow \text { ' }\end{array}$ \\
\hline AU:2a & Please check the setting of Tables 17-2 and 17-3. \\
\hline AU: 3 & $\begin{array}{l}\text { Please check the sense of the sentence 'In all cases, the main } \\
\text { contribution...' }\end{array}$ \\
\hline AU:4 & Please provide figure and captions for citation 17-6. \\
\hline AU:5 & Please check the usage of ' $A s_{w}\left(\% \mathrm{As}_{\text {tot }}\right)$ ' in Table 17-5. \\
\hline AU:6 & $\begin{array}{l}\text { Please check the volume number in reference 'Abrahams and } \\
\text { Thornton, 1987'. }\end{array}$ \\
\hline AU:7 & Please cite 'Juillot et al., 1999' in text. \\
\hline AU:8 & Please update 'Klinck et al., in press'. \\
\hline
\end{tabular}

